UMBARA

Indonesian Journal of Anthropology

Volume 6 (1) Juli 2021 || eISSN 2528-1569 | pISSN 2528-2115 || http://jurnal.unpad.ac.id/umbara

DOI : 10.24198/umbara.v6i1.33631

\title{
Dimensi Gender dalam Pengetahuan tentang Iklim dan Perubahan Iklim pada Masyarakat Pertanian Negara Berkembang
}

\author{
Salsabilla Shofia \\ Program Studi Antropologi, Fakultas Ilmu Sosial dan Ilmu Politik, Universitas Padjadjaran \\ salsabillashof@gmail.com
}

\begin{abstract}
This study discusses differences in the level knowledge about climate and climate change between men and women in agricultural society in low-income countries and how it relates to gender. The study applied systematic review on literatures on climate changes. The study suggests that gender division of labor in agriculture society deeply influence the different knowledge about climate change between men and women. Women tend to have less knowledge than men about the causes of climate change due to women's limited access to education, and sources of information. As the consequence, it is important to promote gender equality to open similar access of men and women to education. Given the similar access to education, women will accumulate equal knowledge to men and women, including knowledge on climate change. The equal knowledge about climate change between men and women will then lead them to contribute equally to the adaptive strategy to climate change.
\end{abstract}

Keywords: gender dimension, climate local knowledge, climate change, agricultural community.

\begin{abstract}
Abstrak
Penelitian ini mengenai perbedaan pengetahuan tentang iklim dan perubahan iklim antara laki-laki dan perempuan di masyarakat pertaninan di negara berkembang. Penelitian ini menggunakan metode studi pustaka. Teknik pengumpulan data dilakukan dengan membaca artikel yang membahas kasus perubahan iklim di masyarakat pertanian di negara-negara berkembang. Hasil studi literatur menunjukkan adanya perbedaan pengetahuan antara laki-laki dan perempuan terkait iklim dan perubahannya. Perbedaan pengetahuan meliputi perbedaan indikator prediksi iklim, yaitu perempuan lebih memperhatikan indikator prediksi iklim di sekitar tempat tinggal, sedangkan laki-laki mengamati indikator prediksi iklim di sekitar ladang tempat bekerja. Perbedaan pengetahuan ini terkait dengan pembagian kerja berdasarkan gender dalam pertanian. Selain itu, keterbatasan akses perempuan pada pendidikan, dan sumber informasi mengarah pada keterbatasan pengetahuan mereka, termasuk pengetahuan tentang iklim dan perubahannya. Oleh karena itu penting dilakukan penyetaraan akses perempuan dan laki-laki terhadap pendidikan agar perempuan dan laki-laki memiliki pengetahuan yang sama terhadap perubahan iklim agar keduanya dapat berkontribusi sejajar dalam upaya menciptakan strategi yang adaptif pada perubahan iklim.
\end{abstract}

Kata kunci: dimensi gender, pengetahuan iklim, perubahan iklim, masyarakat pertanian. 


\section{Pendahuluan}

Penelitian ini membahas dimensi gender dalam pengetahuan masyarakat tentang iklim dan perubahan iklim. Secara lebih khusus penelitian ini melihat pengaruh gender pada perbedaan atau persebaran pengetahuan tentang iklim dan perubahan iklim di masyarakat pertanian di negara berkembang. Pengetahuan yang dimaksud meliputi pengetahuan tentang cara memprediksi iklim, serta pengetahuan tentang perubahan iklim yang terjadi. Pengetahuan masyarakat tentang iklim berperan penting dalam membentuk respon kolektif maupun individual terhadap perubahan iklim.

Masyarakat petani di pedesaan memiliki pengetahuan mendalam tentang variabilitas iklim lokal dan perubahannya; dan hal ini telah menjadi bagian dari pengetahuan ekologi tradisional mereka. Pengetahuan lokal ini bersifat kolektif dan ditransfer dari generasi ke generasi (Berkes et al., 1995 dalam Boissiere et al., 2013). Pengetahuan dan persepsi lokal menjadi dasar bagi masyarakat untuk menanggapi semua gejala perubahan iklim yang beragam dan menyesuaikan dengan kondisi itu; termasuk pada kondisi iklim dan cuaca yang ekstrem dan yang belum pernah mereka alami sebelumnya (Boissiere et al., 2013).

Bagi masyarakat petani, pengetahuan yang mereka miliki tentang iklim dan perubahannya berperan penting dalam pengambilan keputusan terkait aktivitas pertanian. Pengetahuan tersebutlah yang membuat petani menentukan dapat menandai waktuwaktu penting dalam proses pertanian, mulai dari waktu pengolahan tanah, waktu tanam, pengelolaan, hingga panen, dan pasca panen. Seiring berubahnya iklim, pengetahuan petani tentang perubahan tersebut juga memengaruhi proses adaptasi mereka. Petani biasanya mengandalkan ingatan dan pengalaman mereka terkait iklim dan dengan itulah mereka bertahan hidup. Hal ini kemudian membentuk pengetahuan dan pemahaman mereka tentang fenomena iklim dan informasi iklim (Roncoli et al., 2003 dalam Winarto et al., 2013).
Pengetahuan tentang iklim dan perubahannya, ternyata tidak terlepas dari gender. Blaikie (1997) dalam Kisauzi, et al., (2012) menyatakan bahwa pengetahuan (tentang iklim) tidak homogen, tetapi bervariasi antar individu, salah satunya karena perbedaan jenis kelamin. Pada masyarakat pertanian, pembagian kerja produksi juga dilakukan berdasarkan jenis kelamin. Hal ini menghasilkan peran gender yang berbeda antara perempuan dan laki-laki. Perbedaan peran inilah yang memungkinkan adanya variasi pengetahuan berbasis gender, termasuk pengetahuan mengenai perubahan iklim di antara petani laki-laki dan perempuan.

Penelitian Roncoli et al. (2002) di Burkina Faso, menemukan perbedaan pengetahuan tentang cara memprediksi cuaca dan iklim antara perempuan dan laki-laki. Laki-laki memprediksi cuaca di ladang tempat bekerja, sedangkan perempuan memprediksi cuaca di lingkungan sekitar rumahnya. Pembagian peran gender dalam keluarga, yaitu peran domestik bagi perempuan dan peran publik bagi laki-laki membuat mereka berada dalam lokasi yang berbeda. Fenomena serupa juga ditemukan dalam penelitian Garray-Barayazara dan Puri (2011) di Sarawak, Malaysia. Hasil penelitian itu menunjukkan perbedaan pengetahuan antara laki-laki dan perempuan tentang cara memprediksi cuaca. Perempuan lebih memperhatikan prediksi cuaca harian, sedangkan laki-laki memperhatikan prediksi kondisi cuaca mingguan.

Pengetahuan tentang perubahan iklim juga berbeda antara perempuan dan laki-laki. Hasil penelitian Sanchez-Cortez dan Chavero (2011) di Meksiko menemukan bahwa perempuan kurang memiliki pengetahuan tentang cuaca yang berubah dibandingkan laki-laki. Laki-laki lebih memperhatikan dan mengenali gejala-gejala perubahan cuaca dan iklim dari ladang tempatnya bertani. Rupanya aktivitas mereka di ladang memungkinkan mereka mengembangkan kepekaan itu dibandingkan para perempuan yang beraktivitas di sekitar rumah. Hal ini menunjukkan bahwa pemba- 
gian lokasi aktivitas berdasarkan gender terbukti membedakan kemampuan laki-laki dan perempuan dalam pengetahuan mereka tentang iklim. Fenomena serupa juga ditemukan oleh Kisauzi et al. (2012) dalam penelitiannya di Uganda. Ia menemukan laki-laki memiliki lebih banyak pengetahuan tentang penyebab perubahan iklim dibanding perempuan.

Perbedaan pengetahuan mengenai iklim antara laki-laki dan perempuan, berkaitan erat dengan peran sosial perempuan, diskriminasi, dan kemiskinan. Perempuan di masyarakat petani memiliki lebih sedikit akses terhadap sumber daya. Peluang mereka untuk berperan dalam kegiatan produktif lebih kecil dibanding laki-laki.

Dankelman dan Jansen (2010) menyatakan bahwa perempuan cenderung hidup dalam kemiskinan, tidak memiliki akses pada tanah dan sumber daya yang dapat mereka gunakan untuk melindungi mereka dalam situasi pasca bencana. Mereka juga kurang memiliki kendali atas produksi dan pendapatan, kurang pendidikan dan pelatihan, akses yang lebih sedikit terhadap dukungan dan informasi kelembagaan, kurang kebebasan dalam berserikat, dan memiliki posisi yang kecil dalam pembuatan keputusan. Alasan terbesar yang mendorong timbulnya diskriminasi pada perempuan adalah tanggung jawab mereka terhadap orang tua dan anak-anak. Hal ini yang membuat mereka cenderung meninggal dan atau terkena kekerasan selama dan setelah peristiwa iklim (Dankelman dan Jansen, 2010).

Posisi perempuan di masyarakat pertanian memang sangat dirugikan dalam hal akses dan kontrol terhadap sumber daya. Namun, mereka memiliki pengetahuan dan pengalaman yang mereka kumpulkan dari hasil bekerja bertahuntahun di lingkungan alam sekitarnya; dan pengetahuan itu dapat mereka manfaatkan untuk beradaptasi dengan perubahan iklim (Kisauzi et al., 2012).

Penelitian tentang dimensi gender dalam pengetahuan masyarakat tentang iklim dan perubahannya penting untuk dilakukan karena dengan memahami dimensi gender pada pengetahuan tentang iklim dan perubahan iklim, penelitian ini akan berkontribusi memberikan gambaran mengenai strategi adaptasi yang efektif dalam menghadapi perubahan iklim (Kisauzi et al., 2012). Strategi adaptasi yang efektif diperlukan oleh masyarakat untuk mampu bertahan dari perubahan iklim yang akhir-akhir ini terjadi. Pada konteks strategi adaptasi, kesetaraan gender di masyarakat dapat meningkatkan akses perempuan terhadap berbagai hal penting dalam kehidupannya, termasuk dalam hal pengetahuan tentang iklim dan perubahannya. Penelitian ini akan berkontribusi memberikan gambaran mengenai strategi adaptasi yang efektif dalam menghadapi perubahan iklim (Kisauzi et al., 2012).

\section{Kajian Pustaka}

Gender adalah konstruksi sosial-budaya tentang peran, karakter, tugas, aktivitas, tanggung jawab, bagi perempuan dan laki-laki berdasarkan kesepakatan (Kottak, 2011). Kottak (2011) menyebutkan bahwa kebudayaan membedakan dan mengasosisasikan laki-laki dan perempuan ke dalam beragam aktivitas yang berbeda. Seks/jenis kelamin tidak dapat dipertukarkan, baik fisiknya maupun fungsinya dalam reproduksi, sedangkan konsep gender, merujuk pada perbedaan peran antara lakilaki dan perempuan yang sifatnya dapat dipertukarkan. Perempuan identik dengan atribut 'feminin', dan laki-laki identik dengan atribut 'maskulin'. Peran gender merupakan tugas dan aktivitas yang diberikan pada tiap jenis kelamin dan hal ini dipengaruhi oleh budaya. Perbedaan peran antara pekerjaan domestik perempuan dan pekerjaan produktif laki-laki menyebabkan adanya kontras antara laki-laki dengan peran publik dan bernilai, dan perempuan dengan peran domestik dan inferior (Kottak, 2011). Peran dan atribut antara perempuan dan laki-laki dapat berubah dari waktu ke waktu, berbeda dari tempat ke tempat lainnya, dan berbeda dari suatu kelas 
ke kelas sosial lainnya (Fakih, 1999 dalam Ramadhani dan Hubeis, 2020). Oleh karena itu, peran dan ideologi gender berbeda antara satu masyarakat dengan kebudayaan tertentu dan masyarakat dengan kebudayaan lainnya.

\section{Peran Gender dalam Masyarakat Pertanian}

Pembagian peran berdasarkan gender juga terjadi di bidang pertanian. Peran gender dalam pertanian juga berbeda-beda di berbagai latar budaya, tetapi memiliki kesamaan yaitu adanya peran domestik dan peran publik. Peran domestik biasanya diidentikkan dengan perempuan, dan peran publik dengan laki-laki. Di dalam pembagian peran ini, masih terdapat kesenjangan antara peran perempuan dan lakilaki. Perempuan di bidang pertanian memiliki lebih sedikit akses terhadap sumber daya, dan peluang untuk menjadi produktif, dibanding laki-laki (FAO, 2011 dalam Kristjanson et al., 2017).

Kesenjangan gender dalam pertanian tampak dalam kepemilikan aset, input (sarana prasarana pertanian), pelayanan (tanah, ternak, tenaga kerja, teknologi, pendidikan, serta layanan penyuluhan dan keuangan). Padahal, akses terhadap sumber daya yang seimbang antara laki-laki dan perempuan akan memungkinkan perempuan memiliki dan mengendalikan akses produktif, baik itu tingkat produktivitas dalam bekerja maupun tingkat kepercayaan diri/harga diri dari perempuan (Quisumbing et al., 2011 dalam Kristjanson et al., 2017).

\section{Iklim dan Perubahan Iklim}

Iklim adalah tipikal atau keadaan cuaca ratarata di suatu wilayah tertentu dalam jangka panjang (terdiri atas curah hujan, suhu ratarata, kecepatan angin, kelembapan, dan sebagainya), sedangkan perubahan iklim mengacu pada penumpukan gas rumah kaca di atmosfer bumi yang menyebabkan perubahan besar dalam iklim dan peristiwa bencana (United Nations, 1992). Perubahan ini meliputi mencairnya lapisan es di kutub, kenaikan suhu laut dan udara, serta peningkatan peristiwa bencana seperti gelombang badai, siklon yang lebih sering dan lebih ganas, perubahan curah hujan dan kekeringan (IPCC, 2017 dalam Alston, 2014).

Iklim memengaruhi aktivitas manusia dan menjadi faktor yang memengaruhi penentuan waktu-waktu penting dalam kehidupan seharihari manusia. Perubahan yang terjadi pada iklim tentunya berdampak pula bagi perubahan kehidupan manusia. Menurut studi Surmaini et al., (2011), perubahan iklim diyakini akan berdampak buruk terhadap berbagai aspek kehidupan dan sektor pembangunan, terutama sektor pertanian. Perubahan iklim ini dikhawatirkan mendatangkan masalah baru bagi keberlanjutan produksi pertanian, yaitu penurunan produktivitas, degradasi dan penurunan tingkat kesuburan lahan, pencemaran, bencana banjir dan kekeringan, serta alih fungsi lahan pertanian. Oleh karena itu, diperlukan strategi adaptasi yang efektif untuk menghadapi dan mengantisipasi dampak dari perubahan iklim, khususnya bagi sektor pertanian.

\section{Gender dan Perubahan Iklim}

Strategi adaptasi dalam menghadapi perubahan iklim juga terkait erat dengan gender. Berdasarkan UN Women Watch yang dikutip dalam Alston (2014), perempuan lebih rentan terhadap efek perubahan iklim daripada laki-laki, dan menjadi sangat rentan apabila mereka sangat bergantung pada sumber daya alam lokal untuk mata pencahariannya. Perempuan yang diberi tanggung jawab untuk mengamankan air, makanan, dan bahan bakar untuk memasak menghadapi tantangan terbesar terutama karena akses yang tidak setara ke sumber daya dan proses pengambilan keputusan. Perempuan dan laki-laki memiliki perbedaan kebutuhan (strategis dan praktis) dan minat dalam upaya-upaya beradaptasi terhadap perubahan iklim. Namun, mobilitas yang terbatas menempatkan perempuan, khususnya di daerah pedesaan pada posisi tidak seimbang ketika perubahan iklim terjadi.

Peran gender dalam strategi adaptasi menghadapi perubahan iklim berkaitan dengan peran laki-laki dan perempuan sehari-hari di dalam rumah tangga. Menurut 
Kisauzi et al. (2012), salah satu faktor yang mampu berkontribusi penting untuk menemukan strategi adaptasi yang efektif dalam perubahan iklim yaitu dengan cara memahami dimensi gender pada pengetahuan tentang iklim dan perubahan iklim itu sendiri. Hal ini karena pengetahuan tentang iklim dan cuaca menjadi respon mendasar yang akan dilakukan masyarakat ketika dihadapkan pada perubahan iklim.

Pengetahuan laki-laki dan perempuan yang luas tentang lingkungan dan konservasi sumber daya alam harus dipertimbangkan. Kontribusi potensial mereka terhadap mitigasi iklim dengan menjadi bagian dari strategi adaptasi harus digali lebih jauh (Assan, 2015). Seperti halnya laki-laki, perempuan juga memiliki pengetahuan penting yang berguna dalam perencanaan strategi intervensi dan adaptasi terhadap iklim, dan pengembangan strategi untuk mengatasi dampak perubahan iklim yang terkait dengan ketahanan pangan dan kesejahteraan rumah tangga (Assan, et al., 2018).

\section{Metode}

Penelitian ini menggunakan metode studi pustaka. Pustaka yang digunakan adalah artikel jurnal, laporan milik lembaga atau pemerintah, yang dapat dipertanggungjawabkan validitas atau kebenarannya. Artikel yang dijadikan sumber data merupakan kumpulan contoh kasus dari berbagai negara berkembang yang membahas pengetahuan tentang iklim dan perubahan iklim (lihat rincian di tabel 1).
Teknik pengumpulan data dilakukan dengan membaca literatur untuk mendapatkan data-data sekunder di dalamnya. Analisis dilakukan dengan metode analisis data sekunder. Menurut Boslaugh (2007), analisis data sekunder adalah analisis data yang dikumpulkan oleh orang lain.

Data yang dikumpulkan terdiri dari data kualitatif berupa narasi dan data numerik. Data kemudian diklasifikasi ke dalam sub-topik pengetahuan tentang iklim dan pengetahuan tentang perubahan iklim. Data lalu dianalisis dan diinterpretasi sesuai dengan konsep atau teori yang digunakan, untuk kemudian ditarik menjadi kesimpulan.

\section{Hasil dan Pembahasan}

\section{Pengetahuan tentang Iklim}

Pengetahuan masyarakat, khususnya masyarakat petani tentang iklim diantaranya meliputi pengetahuan tentang klasifikasi dan penamaan gejala-gejala iklim, serta pengetahuan tentang cara memprediksi cuaca dan iklim. Persebaran pengetahuan tentang iklim antara laki-laki dan perempuan juga dilihat dari aspek-aspek tersebut.

Pada suatu contoh kasus di Kenyah Badeng, Sarawak, Malaysia menunjukkan bahwa masyarakat di sana bermata pencaharian sebagai petani sawah dan ladang (lahan kering). Orangorang Kenyah Badeng memiliki pengetahuan lokal yang berasal dari kemampuan panca indra untuk mengumpulkan informasi dari fenomena alam seperti awan, angin, suhu,

\begin{tabular}{|c|c|c|c|c|c|c|}
\hline No. & Nama & Tahun & Topik & Lokasi & Metode & Variabel yang diamati \\
\hline & Penulis & & & Penelitian & Penelitian & \\
\hline 1. & $\begin{array}{l}\text { Garray- } \\
\text { Barayazara } \\
\text { dan Puri }\end{array}$ & 2011 & $\begin{array}{l}\text { Pengetahuan lokal } \\
\text { tentang iklim dan } \\
\text { peramalan cuaca }\end{array}$ & $\begin{array}{l}\text { Kenyah } \\
\text { Badeng, } \\
\text { Malaysia }\end{array}$ & Etnografi & $\begin{array}{l}\text { Persepsi dan } \\
\text { klasifikasi musim } \\
\text { dan variabilitasnya, } \\
\text { indikator prediksi } \\
\text { musim yang } \\
\text { diketahui, dan respons } \\
\text { atas gejala iklim. }\end{array}$ \\
\hline 2. & $\begin{array}{l}\text { Roncoli, } \\
\text { Ingram, } \\
\text { dan } \\
\text { Kirshen }\end{array}$ & 2002 & $\begin{array}{l}\text { Pengetahuan lokal } \\
\text { tentang iklim dan } \\
\text { prediksi cuaca }\end{array}$ & $\begin{array}{l}\text { Burkina } \\
\text { Faso }\end{array}$ & Kualitatif & $\begin{array}{l}\text { Pengetahuan } \\
\text { klasifikasi musim, } \\
\text { dan indikator prediksi } \\
\text { musim. }\end{array}$ \\
\hline
\end{tabular}




\begin{tabular}{|c|c|c|c|c|c|c|}
\hline 3. & Jost et al & 2016 & $\begin{array}{l}\text { Dimensi gender } \\
\text { dalam pertanian } \\
\text { dan perubahan } \\
\text { iklim }\end{array}$ & $\begin{array}{l}\text { Ghana, } \\
\text { Uganda, } \\
\text { Bangladesh }\end{array}$ & Kualitatif & $\begin{array}{l}\text { Pengetahuan climate- } \\
\text { smart agriculture, } \\
\text { pendekatan climate } \\
\text { analogue, dan } \\
\text { peramalan cuaca } \\
\text { dan iklim, analisis } \\
\text { berdasarkan gender } \\
\text { dan kelas sosial. } \\
\end{array}$ \\
\hline 4. & $\begin{array}{l}\text { Boissiere } \\
\text { et al }\end{array}$ & 2013 & $\begin{array}{l}\text { Persepsi dan } \\
\text { pengetahuan lokal } \\
\text { atas variabilitas } \\
\text { perubahan iklim }\end{array}$ & $\begin{array}{l}\text { Papua, } \\
\text { Indonesia }\end{array}$ & $\begin{array}{l}\text { Mix- } \\
\text { methods }\end{array}$ & $\begin{array}{l}\text { Persepsi atas } \\
\text { variabilitas dan } \\
\text { perubahan iklim, serta } \\
\text { dampaknya. }\end{array}$ \\
\hline 5. & $\begin{array}{l}\text { Sanchez- } \\
\text { cortez dan } \\
\text { Chavero }\end{array}$ & 2011 & $\begin{array}{l}\text { Persepsi atas } \\
\text { perubahan } \\
\text { variabilitas iklim } \\
\text { dan kaitannya } \\
\text { dengan pertanian }\end{array}$ & $\begin{array}{l}\text { Zoque, } \\
\text { Meksiko }\end{array}$ & $\begin{array}{l}\text { Mix- } \\
\text { methods }\end{array}$ & $\begin{array}{l}\text { Pengetahuan tentang } \\
\text { iklim, persepsi } \\
\text { atas perubahan dan } \\
\text { variabilitas iklim, } \\
\text { serta pengaruh } \\
\text { dan respons dalam } \\
\text { aktivitas pertanian. }\end{array}$ \\
\hline 6. & Postigo & 2014 & $\begin{array}{l}\text { Persepsi dan } \\
\text { ketahanan } \\
\text { masyarakat atas } \\
\text { perubahan iklim }\end{array}$ & Peru & Kualitatif & $\begin{array}{l}\text { Persepsi atas } \\
\text { perubahan iklim, } \\
\text { dampaknya, dan } \\
\text { respons masyarakat. }\end{array}$ \\
\hline 7. & $\begin{array}{l}\text { Kisauzi } \\
\text { et al }\end{array}$ & 2012 & $\begin{array}{l}\text { Dimensi gender } \\
\text { pada persepsi dan } \\
\text { pengetahuan petani } \\
\text { atas perubahan } \\
\text { iklim }\end{array}$ & $\begin{array}{l}\text { Teso, } \\
\text { Uganda }\end{array}$ & $\begin{array}{l}\text { Mix- } \\
\text { methods }\end{array}$ & $\begin{array}{l}\text { Perbedaan persepsi } \\
\text { dan pengetahuan } \\
\text { petani laki-laki dan } \\
\text { perempuan tentang } \\
\text { perubahan iklim. }\end{array}$ \\
\hline 8. & $\begin{array}{l}\text { Legesse, } \\
\text { Ayele, dan } \\
\text { Bewket }\end{array}$ & 2013 & $\begin{array}{l}\text { Persepsi dan } \\
\text { adaptasi petani atas } \\
\text { variabilitas dan } \\
\text { perubahan iklim }\end{array}$ & $\begin{array}{l}\text { Doba, } \\
\text { Ethiopia }\end{array}$ & $\begin{array}{l}\text { Mix- } \\
\text { methods }\end{array}$ & $\begin{array}{l}\text { Perbedaan persepsi } \\
\text { berdasarkan gender } \\
\text { dan kelompok sosial } \\
\text { terkait variabilitas } \\
\text { dan perubahan iklim, } \\
\text { serta respons dan } \\
\text { strategi adaptasi yang } \\
\text { dilakukan berkaitan } \\
\text { dengan aktivitas } \\
\text { pertanian. }\end{array}$ \\
\hline 9. & $\begin{array}{l}\text { Boillat dan } \\
\text { Berkes }\end{array}$ & 2013 & $\begin{array}{l}\text { Persepsi dan } \\
\text { interpretasi } \\
\text { masyarakat atas } \\
\text { perubahan iklim }\end{array}$ & $\begin{array}{l}\text { Quechua, } \\
\text { Bolivia }\end{array}$ & Etnografi & $\begin{array}{l}\text { Persepsi atas } \\
\text { perubahan cuaca dan } \\
\text { iklim, konsekuensi } \\
\text { terhadap pertanian, } \\
\text { respons yang } \\
\text { dilakukan. }\end{array}$ \\
\hline
\end{tabular}

Tabel 1. Ringkasan Literatur yang Digunakan sebagai Contoh Kasus

udara, kelembaban, dan curah hujan sebagai alat prediksi cuaca serta pengaruhnya pada praktik sehari-hari. Pengetahuan mereka terkait penamaan dan klasifikasi berbagai gejala keikliman dapat terlihat dari nama-nama musim, jenis-jenis hujan, awan, dan benda-benda langit lainnya yang mereka beri nama menggunakan bahasa lokal yang mereka gunakan sehari-hari. Pada pengetahuan tentang penamaan ini, tak ada perbedaan tingkat dan sebaran pengetahuan antara laki-laki dan perempuan, tetapi perbedaan terlihat pada pengetahuan tentang 
cara memprediksi cuaca (Garray-Barayazara dan Puri, 2011). kolam dan sumur, serta mengamati produksi buah liar yang mereka kumpulkan. Mereka

\begin{tabular}{ll}
\hline \multicolumn{1}{c}{ Perempuan } & \multicolumn{1}{c}{ Laki-laki } \\
\hline - $\begin{array}{l}\text { Memperhatikan prediksi cuaca harian - } \\
(12-1 \text { jam yang akan datang) }\end{array}$ & $\begin{array}{l}\text { Memperhatikan prediksi cuaca mingguan, } \\
\text { (3-6 hari yang akan datang) }\end{array}$ \\
\hline - $\begin{array}{l}\text { Ketika dirasa akan turun hujan: mena- } \\
\text { nam bibit, mengumpulkan hasil panen dan } \\
\text { menjualnya ke pasar keesokan harinya, } \\
\text { mengangkat jemuran baju dan hasil panen, } \\
\text { mengamankan kayu bakar. }\end{array}$ & $\begin{array}{l}\text { Ketika dirasa tak akan turun hujan: } \\
\text { meninggalkan ladang pertanian, merepara- } \\
\text { si alat-alat yang rusak. }\end{array}$ \\
\hline $\begin{array}{l}\text { Ketika dirasa tak akan turun hujan: men- } \\
\text { cuci kain tebal, dan menjemur beras atau } \\
\text { biji lada }\end{array}$ & $\begin{array}{l}\text { Ada laki-laki yang dituakan (sema- } \\
\text { cam dukun), disebut da malan, biasa } \\
\text { diminta memprediksi cuaca, menen- } \\
\text { tukan waktu-waktu memulai pertanian } \\
\text { memiliki pengetahuan dan pengalaman } \\
\text { lebih, sehingga dipercaya masyarakat. }\end{array}$ \\
\hline
\end{tabular}

Tabel 2. Perbedaan Pengetahuan Prediksi Cuaca di Kenyah Badeng (Sumber: Diolah dari data penelitian Garray-Barayazara dan Puri (2011))

Pada contoh kasus lainnya, laki-laki dan perempuan di masyarakat pertanian di Burkina Faso juga memiliki perbedaan pengetahuan dalam memprediksi cuaca. Meski begitu, perbedaan yang ada berupa perbedaan pengetahuan atas jenis indikator prediksi musim, bukan perbedaan tingkat pengetahuan. Di dalam kelompok petani Burkina Faso, pembagian kerja berdasarkan gender memengaruhi pengetahuan masyarakat tentang fenomena iklim dan musim. Lakilaki yang sebagian besar kegiatannya meliputi berladang dan menggembalakan ternak, mengamati dan memprediksi musim lewat siklus hidup burung yang bersarang di gunung/ lembah tempat mereka bekerja. Di sisi lain, para perempuan dengan peran domestiknya dalam urusan rumah tangga memiliki aktivitas yang memungkinkan mereka memiliki pengetahuan atas tanda-tanda turunnya hujan di lingkungan sekitar rumah (Roncoli et al., 2002).

Di dalam kasus ini, perempuan dari kelompok petani sebagian besar beraktivitas di dalam dan di sekitar kompleks rumah tangga, seperti menimba air, memasak, dan membersihkan rumah. Beberapa perempuan juga mengumpulkan air dan kayu sehingga memperluas wilayah pengamatan mereka ke kawasan semak liar. Para perempuan menandai fluktuasi ketinggian air di juga mengamati perilaku serangga di sumber air dan tumpukan sampah. Mereka mengamati jenis serangga yang dianggap menandai terjadinya musim baik apabila larvanya mengisi sarang penuh dengan tanah saat hujan pertama. Selain itu, perempuan memperhatikan apabila banyak lalat dan capung di masa penanaman jagung, maka produksi jagung akan baik karena hujan akan sering turun.

Hasil yang serupa ditemukan juga pada penelitian yang dilakukan Jost et al. (2016) di tiga negara yaitu Uganda, Bangladesh, dan Ghana. Perbandingan dari tiga negara ini menemukan adanya perbedaan pengetahuan terkait prediksi iklim dan musim antara perempuan dan laki-laki. Di Uganda, baik laki-laki maupun perempuan memiliki pemahaman yang kurang akan prediksi musim, tetapi perempuan jauh lebih sedikit mengetahui tentang prediksi musim tersebut. Perempuan tampak tidak dapat memahami ramalan musim atau implikasinya terhadap pengambilan keputusan di bidang pertanian, sementara laki-laki dapat melakukannya. Hasil yang cukup berbeda ditemukan di Ghana. Mayoritas penduduknya masih memiliki dan memelihara pengetahuan lokal tentang prediksi iklim, dan tidak ada perbedaan siginifikan antara perempuan dan laki-laki. 
Selain pengetahuan yang didapat dari warisan generasi ke generasi, pengetahuan tentang iklim juga didapat dari dunia luar seiring perkembangan teknologi yang semakin modern (Jost et al., 2016). Berbagai teknologi ramalan cuaca lokal mulai dikenal dan disosialisasikan di masyarakat pertanian. Di tiga negara yang dijadikan lokasi penelitian, laki-laki dan perempuan mendapatkan pengetahuan tersebut melalui berbagai teknologi yang berbeda.

Di Uganda, laki-laki lebih suka mendapatkan informasi cuaca dan iklim melalui radio, sedangkan perempuan lebih suka mendapatkan informasi ini melalui megafon, surat, pengumuman kepala desa, kelompok tani, anak sekolah, pertemuan keagamaan dan sosial, serta media cetak, bergantung kepentingannya. untuk pengambilan keputusan pertanian.

\section{Pengetahuan tentang Perubahan Iklim}

Pengetahuan tentang perubahan iklim dan persebarannya juga dipengaruhi oleh dimensi gender. Salah satu contoh kasus yaitu penelitian di Mamberamo, Papua, Indonesia (Boissiere et al., 2013). Penelitian ini dilakukan di empat desa di wilayah Mamberamo. Masyarakat di Mamberamo merupakan kelompok masyarakat yang memperoleh penghidupan dengan cara bertani di lahan hutan seperti menanam pisang, kakao, sagu dan tanaman budidaya lainnya. Penelitian ini menemukan bahwa terdapat perbedaan pengetahuan dan persepsi laki-laki dan perempuan

\section{Perempuan}

Laki-laki

- Perubahan iklim didominasi hujan lebat, banjir, dan angin kuat; musim hujan lebih panjang dari biasanya: berdampak pada pertanian jangka panjang; musim kemarau panjang: berdampak pada pertanian jangka pendek.

- Lebih menyoroti tentang hujan lebat dan tanaman apa yang cocok ditanam ketika kemarau/musim hujan panjang terjadi.

- Lebih menyoroti tentang kekeringan dan bagaimana strategi mereka untuk mencari air ketika kemarau.

- Fenomena iklim yang berubah memegaruhi wilayah bercocok tanam mereka.

- Fenomena iklim yang berubah memengaruhi ketersediaan satwa liar yang akan diburu.

Tabel 3. Perbedaan Pengetahuan tentang Perubahan Iklim di Mamberamo, Papua (Sumber: Diolah dari data penelitian Boissiere et al., 2013))

Meski begitu, baik perempuan maupun laki-laki lebih mempercayai prediksi cuaca yang didapat dari para tetua di keluarga mereka, dibandingkan dari hasil teknologi modern.

Di Ghana, informasi cuaca dan iklim mudah diakses dan dianggap dapat diandalkan oleh perempuan dan laki-laki melalui siaran radio. Informasi tersebut disebarluaskan di berbagai pertemuan publik kepada perempuan dari rumah tangga miskin yang tidak memiliki radio. Laki-laki juga mengakses informasi ini dari televisi. Perempuan menggunakan informasi cuaca untuk membuat keputusan tentang mobilitas, sementara laki-laki menggunakannya tentang fenomena perubahan variabilitas musim dan iklim lokal yang dapat dilihat pada tabel 3 .

Perbedaan pengetahuan ini disebabkan oleh adanya perbedaan peran dan aktivitas yang dilakukan oleh perempuan dan laki-laki. Hal tersebut menghasilkan perbedaan pengetahuan tentang lingkungan, khususnya dalam hal ini pengetahuan tentang iklim dan perubahannya. Adanya perbedaan tersebut juga dipengaruhi oleh pengalaman berbeda yang dialami laki-laki dan perempuan terkait pola iklim dan perubahannya.

Pada kasus lainnya di Zoque, Meksiko, terdapat perbedaan pengetahuan dan persepsi an- 
tara perempuan dan laki-laki terkait perubahan variabilitas iklim (Sanchez-Cortez dan Chavero, 2011). Aspek yang disebut sebagai indikator perubahan variabilitas iklim meliputi berkurangnya curah hujan, berkurangnya durasi angin Utara, serta peningkatan suhu udara. Perempuan lebih sedikit mengetahui dan menyadari perubahan curah hujan dan peningkatan suhu udara dibandingkan laki-laki.

Aspek lainnya dari kasus di Zoque yaitu pengetahuan tentang penyebab perubahan iklim. Penyebab perubahan iklim di sana terdiri atas dua faktor yaitu erupsi gunung Chichon (penyebab alami), dan kerusakan alam oleh manusia. Laki-laki lebih banyak menyebutkan dan mengetahui tentang kedua penyebab tersebut dibandingkan perempuan. Berdasarkan hasil tersebut, perempuan lebih sedikit menyebutkan tentang perubahan pada siklus iklim lokal, dibandingkan dengan laki-laki. Perempuan kurang memiliki pengetahuan tentang perubahan iklim, sedangkan laki-laki lebih memerhatikan dan mengenali gejalagejala perubahan cuaca dan iklim. Hal ini disinyalir karena peran perempuan di sektor domestik atau rumah tangga tidak terlibat aktif dalam aktivitas pertanian, dan sedikit membatasi kegiatan mereka ke ladang. Mereka hanya membantu ketika panen. Pengetahuan lebih tentang perubahan iklim dan penyebabnya dimiliki oleh laki-laki yang lebih sering berhubungan dengan alam ketika melakukan aktivitas pertanian.

Hal serupa ditemukan pada penelitian Postigo (2014) di Andean, Peru. Perbedaan peran laki-laki dan perempuan dalam aktivitas pertanian menimbulkan perbedaan pengetahuan dan strategi yang dilakukan. Secara umum, keseluruhan informan, baik laki-laki maupun perempuan, memiliki pengetahuan yang cenderung seragam atas terjadinya perubahan iklim. Mereka mempersepsikan iklim telah berubah, suhu udara meningkat, curah hujan menjadi tak menentu, dan kekeringan sering terjadi. Meski begitu, pada penelitian ini para petani perempuan melakukan diskusi grup secara khusus. Di dalam diskusi grup itu, diketahui bahwa para petani perempuan memodifikasi kalender pertanian untuk menye- suaikan dengan pola hujan yang telah berubah berdasarkan pengetahuan sebelumnya. Para perempuan juga mempersepsikan bahwa perubahan iklim terjadi, ditandai dengan adanya kenaikan suhu udara yang menyebabkan munculnya banyak penyakit pada hewan ternak dan hama pada tanaman.

Hal cukup berbeda ditemukan pada kasus di Teso, Uganda Timur (Kisauzi et al., 2012). Pada penelitian ini tidak ditemukan perbedaan yang signifikan tentang pengetahuan dan persepsi antara perempuan dan laki-laki terhadap ciri-ciri perubahan iklim. Perempuan dan laki-laki sama-sama mengetahui ciri-ciri perubahan iklim, seperti panjangnya musim yang berubah, suhu udara naik, banjir, kekeringan, dan angin kencang sering terjadi. Meskipun begitu, perempuan lebih menyadari adanya peningkatan frekuensi kejadian kekeringan dibanding laki-laki. Hal ini karena laki-laki dan perempuan memiliki perannya masing-masing yang sama-sama terganggu ketika perubahan iklim terjadi. Perempuan bertanggung jawab atas ketersediaan makanan di rumah tangga dan rentan terganggu ketika terjadi kekeringan, ataupun banjir, sedangkan laki-laki yang perannya beternak sapi terganggu ketika angin kencang terjadi karena dapat memengaruhi keselamatan ternak.

Perbedaan pengetahuan tentang iklim antara laki-laki dan perempuan di masyarakat Andean terletak pada pengetahuan tentang penyebab perubahan iklim. Laki-laki lebih banyak mengetahui penyebab perubahan iklim dibandingkan perempuan. Sebaliknya, perempuan banyak yang tidak mengetahui penyebab perubahan iklim, atau tidak akurat dalam memberikan pandangan terkait penyebab perubahan iklim. Berdasarkan temuan tersebut, perempuan terutama perempuan kepala keluarga - hampir sebelas kali lebih sedikit mengetahui, dan salah mempersepsikan penyebab perubahan iklim. Perbedaan ini disebabkan oleh tidak setaranya akses terhadap pendidikan, keanggotaan organisasi tani, akses terhadap radio sebagai sumber informasi, dan sebagainya. Perempuan memiliki lebih sedikit akses terhadap berbagai hal tersebut sehingga pengetahuannya pun lebih sedikit dibanding laki-laki. 
Penelitian Legesse, Ayele, dan Bewket (2013) yang dilakukan di Doba, Ethiopia, juga menemukan bahwa pengetahuan laki-laki dan perempuan terkait terjadinya perubahan iklim cenderung seragam dalam beberapa aspek, meski terdapat perbedaan tetapi tidak cukup signifikan. Rincian persentase terkait persepsi kepala keluarga laki-laki dan perempuan terkait variabel perubahan iklim dapat dilihat pada tabel 4 berikut.
Pengetahuan tentang iklim dan perubahan iklim pada masyarakat pertanian di berbagai negara berkembang menunjukkan adanya perbedaan antara perempuan dan laki-laki. Perbedaan ini berupa perbedaan jenis dan variasi pengetahuan yang dipengaruhi oleh perbedaan peran dalam aktivitas mata pencaharian sehari-hari yaitu perempuan yang cenderung berperan lebih besar di ranah domestik dan laki-laki yang berperan lebih besar di ranah publik (ladang).

\begin{tabular}{lcccccc}
\hline \multirow{2}{*}{ Variabel } & \multicolumn{3}{c}{ Kepala Keluarga Laki-laki } & \multicolumn{3}{c}{ Kepala Keluarga Perempuan } \\
\cline { 2 - 7 } & $\mathbf{M}$ & $\mathbf{T}$ & $\mathbf{B}$ & $\mathbf{M}$ & $\mathbf{T}$ & $\mathbf{B}$ \\
\hline Suhu udara & $99,3 \%$ & $0,7 \%$ & 0 & $100 \%$ & 0 & 0 \\
\hline Curah hujan tak tentu & $100 \%$ & 0 & 0 & $100 \%$ & 0 & 0 \\
\hline Presipitasi & 0 & $2,2 \%$ & $97,8 \%$ & 0 & $9,5 \%$ & $90,5 \%$ \\
\hline Kekeringan & $94,2 \%$ & $5,8 \%$ & 0 & $100 \%$ & 0 & 0 \\
\hline
\end{tabular}

Ket: $\mathrm{M}=$ Meningkat; $\mathrm{T}=$ Tidak ada perubahan; $\mathrm{B}=$ Berkurang.

Tabel 4. Persepsi terkait Variabel Perubahan Iklim berdasarkan Jenis Kelamin Kepala Keluarga (Sumber: Diolah dari penelitian Legesse, B., Ayele, Y., dan Bewket, W. (2013))

Berdasarkan tabel 4 di atas, dapat terlihat bahwa rata-rata informan, baik kepala keluarga laki-laki maupun perempuan, memiliki persepsi yang serupa atas variabel terjadinya perubahan iklim. Hal ini ditunjukkan dari selisih persentase yang tidak lebih dari $6 \%$ untuk tiap variabel.

Satu lagi penelitian oleh Boillat dan Berkes (2013) yang menemukan tidak adanya perbedaan signifikan terkait pengetahuan laki-laki dan perempuan atas perubahan iklim. Penelitian ini menunjukkan bahwa pengetahuan, termasuk persepsi dan interpretasi perubahan iklim cenderung seragam antar kategori masyarakat, baik perempuan dan laki-laki, juga antara generasi muda dan tua.

Dimensi gender dalam pengetahuan tentang iklim dan perubahannya menunjukkan bahwa di beberapa komunitas masyarakat, terdapat perbedaan tingkat pengetahuan antara perempuan dan laki-laki terkait perubahan iklim. Di sisi lain, di beberapa kelompok masyarakat yang lain tidak ditemukan perbedaan yang signifikan antara pengetahuan perempuan dan laki-laki.

\section{Simpulan}

Pengetahuan tentang perubahan iklim yang dimiliki oleh laki-laki dan perempuan pada masyarakat pertanian secara umum tidak menunjukkan perbedaan yang signifikan. Berdasarkan beberapa penelitian sebelumnya, tidak nampak perbedaan pengetahuan berdasarkan gender. Sebagian alasannya yaitu karena beberapa penelitian tersebut tidak berfokus pada analisis aspek atau dimensi gender, melainkan menjadikannya sebagai salah satu variabel analisis yang umum.

Perbedaan pengetahuan berdasarkan gender yang terjadi di beberapa komunitas secara garis besar disebabkan oleh perbedaan tingkat pengetahuan tentang penyebab dari perubahan iklim. Perempuan lebih sedikit mengetahui tentang penyebab perubahan iklim dibanding laki-laki karena perempuan lebih sedikit memiliki akses terhadap pendidikan dan sumber-sumber informasi (radio, penyuluhan, dan organisasi). Hal ini pula melemahkan kapasitas perempuan dalam beradaptasi dengan perubahan iklim.

Pengetahuan lokal masyarakat terkait iklim merupakan faktor penting untuk menemukan strategi adaptasi yang efektif dalam mengatasi 
perubahan iklim. Hal ini karena respons mendasar yang dilakukan masyarakat atas perubahan iklim berdasarkan pada pengetahuannya terhadap iklim dan cuaca. Oleh karena itu, penting untuk melihat temuan dari penelitian-penelitian yang dipaparkan di atas, bahwa pada beberapa komunitas di negara berkembang, terdapat perbedaan variasi serta tingkat pengetahuan antara perempuan dan laki-laki terkait iklim dan perubahannya. Berdasarkan temuan ini, alasan untuk memperhatikan dimensi gender dalam kebijakan dan program terkait adaptasi perubahan iklim menjadi semakin kuat.

Program-program terkait adaptasi iklim harus mempertimbangkan variasi berdasarkan gender. Sebelum itu, ada hal mendasar yang perlu untuk dilakukan terlebih dahulu, yaitu membuka dan menyetarakan akses selua-luasnya terhadap pendidikan, sumber informasi, teknologi, kepemilikian modal, dan sebagainya kepada perempuan maupun laki-laki. Akses yang setara, khususnya bagi perempuan, dapat mengurangi kesenjangan tingkat pengetahuan tentang iklim dan perubahannya. Oleh karena itu semua anggota masyarakat akan memiliki persepsi yang sama terkait hal-hal yang harus dilakukan dalam merespons dan mengerahkan strategi adaptasi atas perubahan iklim tersebut.

\section{Daftar Pustaka}

Alston, M. (2014). Gender Mainstreaming and Climate Change. Women's Studies International Forum, 47, 287-294.

Assan, E., Suvedi, M., Shmit, O. L., dan Allen, A. (2018). Coping with and Adapting to Climate Change: A Gender Perspective to Climate Change: A Gender Perspective from Smallholder Farming in Ghana. Environments, 5(8), 86.

Assan, N. (2015). Gender Diferrentiated Climate Change Discourse in Rural Communities in Developing Countries. Scientific Journal of Pure and Applied Sciences, 4(2), 34-38.

Boillat, S., dan Berkes, F. (2013). Perception and Interpretation of Climate Change among Quechua Farmers of Bolivia: Indigenous Knowledge as a Resource for Adaptive
Capacity. Ecology and Society, 18(4), 21.

Boissiere, M., Locatelli, B., Sheil, D., Padmanaba, M., dan Sadjudin, E. (2013). Local Perceptions of Climate Variability and Change in Tropical Forests of Papua Indonesia. Ecology and Society, 18(4), 13.

Boslaugh, S. (2007). An Introduction to Secondary Data Analysis. In Secondary Data Sources for Public Health, 2-10.

Dankelman, I. E. M., dan Jansen, W. H. M. (2010). Gender, Environment, and Climate Change: Understanding the Linkages. London: Routledge.

Garray-Barayazara, G., dan Puri, R. K. (2011). Smelling the Monsoon: Senses and Traditional Weather Forecasting Knowledge among the Kenyah Badeng Farmers of Sarawak, Malaysia. Indian Journal of Traditional Knowledge, 10(1), 21-30.

Jost, C., Kyazze, F., Naab, J., Neelormin, S., Kinyangi, J., Zougmore, R., Kristjanson, P. (2016). Understanding Gender Dimensions of Agriculture and Climate Change in Smallholder Farming Communities. Climate and Development, 8(2), 133-144.

Kisauzi, T., Mangheni, M. N., Sseguya, H., dan Bashaasha, B. (2012). Gender Dimension of Farmers Perception and Knowledge on Climate Change in Teso Sub-region, Eastern Uganda. African Crop Science Journal, 20(2), 275-286.

Kottak, C. P. (2011). Cultural Anthropology: Appreciating Cultural Diversity. New York: McGraw-Hill Education.

Kristjanson, P., Bryan, E., Bernier, Q., Twyman, J., Meinzen-Dick, R., Kieran, C., Doss, C. (2017). Addressing Gender in Agricultural Research for Development in the Face of a Changing Climate: Where are We and Where Should We be Going? International Journal of Agricultural Sustainability, 15(5), 482500 .

Legesse, B., Ayele, Y., dan Bewket, W. (2013). Smallholder Farmer's Perceptions and Adaptation to Climate Variability and Climate Change in Doba District, West Hararghe, Ethiopia. Asian Journal of Empirical Research, 3(3), 251-265.

Martono, N. (2011). Metode Penelitian Kuantitatif: Analisis Isi dan Analisis Data Sekunder. Jakarta: Raja Grafindo Persada.

Postigo, J. C. (2014). Perception and Resilience of Andean Populations Facing Climate Change. Journal of Ethnobiology, 34(3), 384-400. 
Ramadhani, F. P., dan Hubeis, A. V. (2020). Analisis Gender dalam Upaya Adaptasi dan Mitigasi Perubahan Iklim Rumah Tangga Pertanian. Jurnal Sains Dan Komunikasi Pengembangan Masyarakat, 4(2), 155-166.

Roncoli, C., Ingram, K., dan Kirshen, P. (2002). Reading the Rains: Local Knowledge and Rainfall Forecasting in Burkina Faso. Society and Natural Resources, 15, 409-427.

Sanchez-Cortez, M. S., dan Chavero, E. L. (2011). Indigenous Perception of Changes in Climate Variability and its Relationship with Agriculture in a Zoque Commmunity of Chiapas, Mexico. Climatic Change, 107, 363-389.

Surmaini, E., Runtunuwu, E., dan Las, I. (2011). Upaya Sektor Pertanian dalam Menghadapi Perubahan Iklim. Jurnal Litbang Pertanian, 30(1), 1-7.

United Nations. United Nations Framework Convention on Climate Change. (1992).

Winarto, Y., Stigter, K., Dwisatrio, B., Nurhaga, M., dan Bowolaksono, A. (2013). Agrometeorological Learning Increasing Farmers Knowledge in Coping with Climate Change and Unusual Risks. Southeast Asian Studies, 2(2), 323-349. 